\title{
norden
}

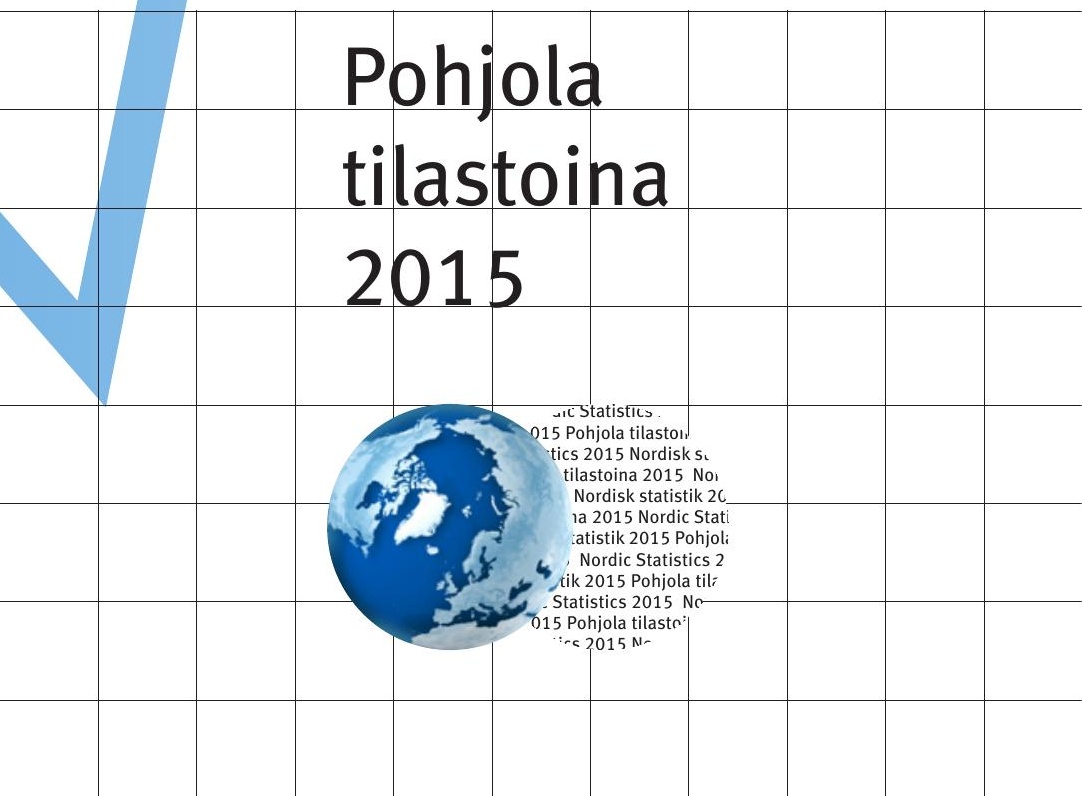




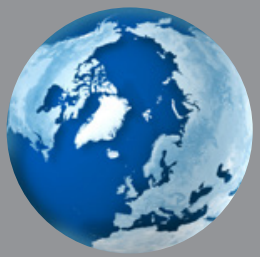

stausul

u15 Pohjola tilasto.

statistics 2015 Nordisk s

Pohjola tilastoina 2015 No stics 2015 Nordisk statistik 21 ola tilastoina 2015 Nordic Stat i Nordisk statistik 2015 Pohjol jina 2015 Nordic Statistics:k statistik 2015 Pohjola til rdic Statistics $2015 \mathrm{Nr}$ 715 Pohjola tilastr

- inic.. 


\title{
nordan
}

\author{
Pohjola \\ tilastoina \\ 2015
}




\section{Pohjola tilastoina 2015}

ISBN 978-92-893-4368-8 (PRINT)

ISBN 978-92-893-4369-5 (PDF)

ISSN 0908-4339

http://dx.doi.org/10.6027/ANP2015-782

ANP 2015:782

(C) Pohjoismaiden ministerineuvosto, 2015

Kansi: Jette Koefoed/ImageSelect.

Kuvat s. 8-9: (C) ImageSelect ja Pohjoismaiden ministerineuvosto

Paino: Rosendahls-Schultz Grafisk A/S

Painos: 500. Printed in Denmark

Pääasialliset tietolähteet: Pohjoismaiden kansalliset tilastokeskukset.

Toimittajat: Klaus Munch Haagensen, Danmarks Statistik (Tanskan tilastokeskus), Niels Stern ja Johannes Magnus, Pohjoismaiden ministerineuvosto.

Tietokanta: Troels A. Vestergaard, Danmarks Statistik (Tanskan tilastokeskus).

\section{Pohjoismainen yhteistyö}

Pohjoismainen yhteistyö on yksi maailman laajimpia alueellisia yhteistyömuotoja. Yhteistyön piiriin kuuluvat Islanti, Norja, Ruotsi, Suomi ja Tanska sekä Ahvenanmaa, Färsaaret ja Grönlanti.

Pohjoismaista yhteistyötä tehdään politiikan, talouden ja kulttuurin aloilla tärkeänä osana eurooppalaista ja kansainvälistä yhteistyötä. Pohjoismaisen yhteisön tavoitteena on vahva Pohjola vahvassa Euroopassa.

Pohjoismainen yhteistyö pyrkii vahvistamaan pohjoismaisia ja alueellisia etuja ja arvoja globaalissa maailmassa. Maiden yhteiset arvot lujittavat osaltaan Pohjolan asemaa yhtenä maailman innovatiivisimmista ja kilpailukykyisimmistä alueista.

\section{Pohjoismaiden ministerineuvosto}

Ved Stranden 18

DK-1061 København K

www.norden.org 


\section{Esipuhe}

Pohjoismaat ovat yksittäin pieniä, mutta yhdessä niiden merkitys kasvaa. Tiesitkö, että Pohjola muodostaa maailman kahdenneksitoista suurimman talouden, kun maiden bruttokansantuotteet lasketaan yhteen? Tai että Pohjola on pinta-alaltaan suurempi kuin Intia, mikä tekee Pohjolasta maailman seitsemänneksi suurimman alueen?

Pohjola tilastoina 2015 antaa pienen katsauksen lukuihin, jotka kuvaavat Pohjolan yhteiskuntia. Tiesitkö esimerkiksi, että islantilaiset käyvät teatterissa kaksi kertaa niin usein kuin norjalaiset, tanskalaiset ja ruotsalaiset?

Mikäli haluat tutustua pohjoismaisiin tilastoihin tarkemmin, vieraile osoitteessa www.norden.org/tietoa. Sivustolta pääsee esimerkiksi pohjoismaiseen tilastopankkiin, jossa on lisää mielenkiintoisia lukuja vertailtavaksi.

\section{Mukavia lukuhetkiä!}

Lisää tilastoja osoitteessa www.norden.org/tietoa
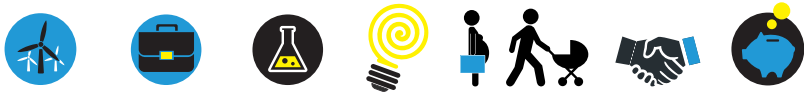


\section{Symbolit}

Ei yhtään

Vähemmän kuin puolet

0

Tieto ei ole sovellettavissa

Tieto puuttuu

Linkki tietokantaan 
Sisällys / teemat

$\begin{array}{ll}\text { Pohjoismaat } & 8\end{array}$

.. statisur

J15 Pohjola tilasto. statistics 2015 Nordisk = Pohjola tilastoina 2015 No stics 2015 Nordisk statistik 2 ola tilastoina 2015 Nordic Stat ; Nordisk statistik 2015 Pohjol jina 2015 Nordic Statistics 2 'k statistik 2015 Pohjola til rdic Statistics 2015 N 15 Pohjola tilastr - กn1 $\mathrm{E}$.

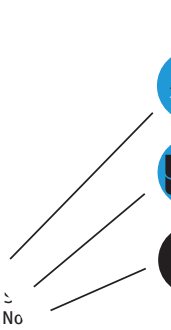

S...... Koulutus ja tutkimus

Innovaatio ja luovuus

$>$ Sosiaalipalvelut ja 

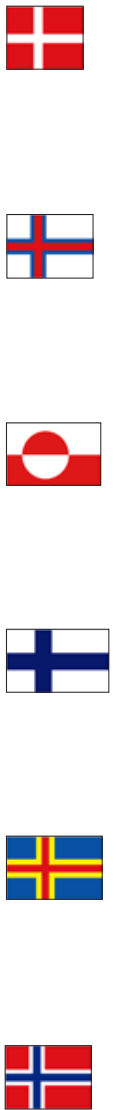

\section{Norja}

Pinta-ala km²

Asukasluku

Valtiomuoto

Valtionpäämies

Pääkaupunki

Valtionpäämies

Suomi

Valtiomuoto

Pääkaupunki

Valtionpäämies
43561

5659715

Perustuslaillinen kuningaskunta

Kuningatar Margareeta II

1263698

1396

48704

Itsehallinto, osa Tanskan kuningaskuntaa

Kuningatar Margareeta II

20235

\section{6}

\section{4}

Itsehallinto, osa Tanskan kuningaskuntaa

Kuningatar Margareeta II

16992
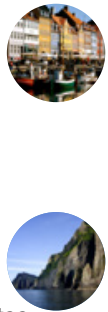

Pinta-ala km²

338430

5471753

Tasavalta

Presidentti Sauli Niinistö

1106418

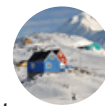

1580

28916

Itsehallinto, osa Suomen tasavaltaa

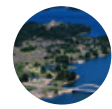

Presidentti Sauli Niinistö

11480

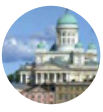

323771

5165802

Perustuslaillinen kuningaskunta Kuningas Harald V

1232575 

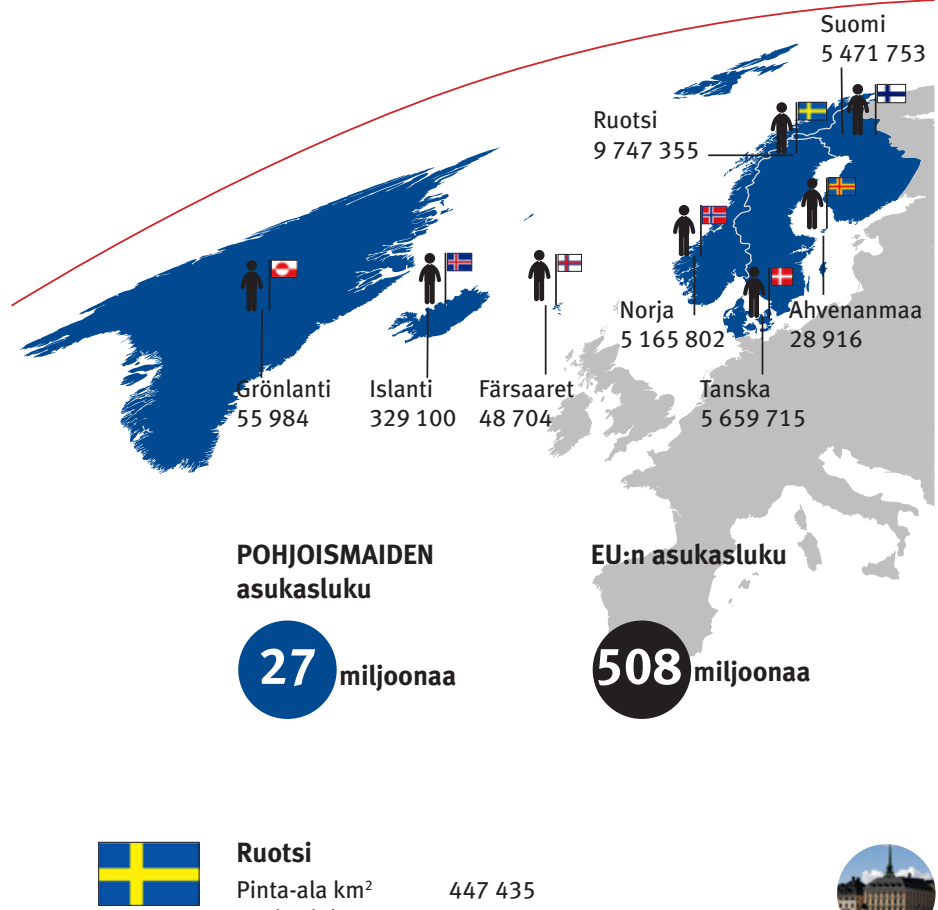

\section{Ruotsi}

Pinta-ala $\mathrm{km}^{2}$

447435

Asukasluku

9747355

Valtiomuoto

Perustuslaillinen kuningaskunta

Valtionpäämies

Kuningas Kaarle XVI Kustaa

Pääkaupunki

2198044

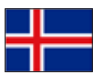

\section{Islanti}

Pinta-ala $\mathrm{km}^{2}$

103492

Asukasluku

Valtiomuoto

329100

Valtionpäämies

Tasavalta

Pääkaupunki

Presidentti Ólafur Ragnar Grímsson

211282
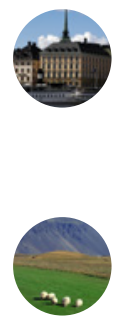
Pohjoismaat kansainvälisissä yhteyksissä - avainluvut $2014^{1}$

\begin{tabular}{|c|c|c|c|c|}
\hline & $\begin{array}{r}\text { Pohjois- } \\
\text { maat }\end{array}$ & EU & Japani & $\begin{array}{l}\text { Yhdys- } \\
\text { vallat }\end{array}$ \\
\hline \multirow{3}{*}{$\begin{array}{l}\text { okonaispinta-ala, } 1000 \mathrm{~km}^{2} \\
\text { Peltoa, prosenttia pinta-alasta } \\
\text { Metsää, prosenttia } \\
\text { pinta-alasta }\end{array}$} & 1147 & 4236 & 378 & 9832 \\
\hline & 7.3 & 28.4 & 12.5 & 44,7 \\
\hline & 56.1 & 37.7 & 68.6 & 33.3 \\
\hline Väkiluku, miljoonaa & 27 & 508 & 128 & 309 \\
\hline Asukkaita $/ \mathrm{km}^{2}$ & 17 & 120 & 339 & 32 \\
\hline $\begin{array}{l}\text { Kokonaishedelmällisyysluku } \\
\text { Keskimääräinen elinikä, } \\
\text { vuosia }\end{array}$ & 1.8 & 1.6 & 1.4 & 1.9 \\
\hline miehet & 79.8 & 77.8 & 79.9 & 76.4 \\
\hline naiset & 84.1 & 83.3 & 86.4 & 81.2 \\
\hline \multirow{3}{*}{$\begin{array}{l}\text { Työttömyysprosentti } \\
\text { miehet } \\
\text { naiset }\end{array}$} & 6,9 & 11,0 & 4 & 7,4 \\
\hline & 7,2 & 11,0 & 4,3 & 7,6 \\
\hline & 6,6 & 11,0 & 3,7 & 7,1 \\
\hline $\begin{array}{l}\text { BKT, mrd. Yhdysvaltain } \\
\text { dollaria } \\
\text { BKT henkeä kohti }\end{array}$ & 1256 & 18430 & 4636 & 17419 \\
\hline Yhdysvaltain dollareissa & 47598 & 34083 & 36485 & 54639 \\
\hline \multirow{2}{*}{$\begin{array}{l}\text { Kokonaisveroaste, } \\
\text { prosenttia BKT:sta } \\
\text { Kokonaisveroaste/asukas } \\
\text { Yhdysvaltain dollareissa }\end{array}$} & 43.8 & 48.6 & 29.5 & 25.4 \\
\hline & 28961 & 16088 & 13711 & 13783 \\
\hline $\begin{array}{l}\text { Tuonti CIF-määräisenä (mrd. } \\
\text { Yhdysvaltain dollaria) } \\
\text { Vienti FOB-määräisenä (mrd. }\end{array}$ & 432 & 2227 & 785 & 2295 \\
\hline $\begin{array}{l}\text { Yhdysvaltain dollaria) } \\
\text { Kauppatase (mrd. }\end{array}$ & 530 & 2256 & 695 & 1593 \\
\hline Yhdysvaltain dollaria) & 98 & 29 & -90 & -702 \\
\hline
\end{tabular}

${ }^{1} 2014$ tai uusin saatavilla oleva luku. Tässä taulukossa Pohjoismaat käsittävät Islannin, Norjan, Ruotsin, Suomen ja Tanskan. EU: Euroopan unionin 27 tai 28 jäsenmaata 1. tammikuuta 2013 tai 1. tammikuuta 2014 lähtien. 


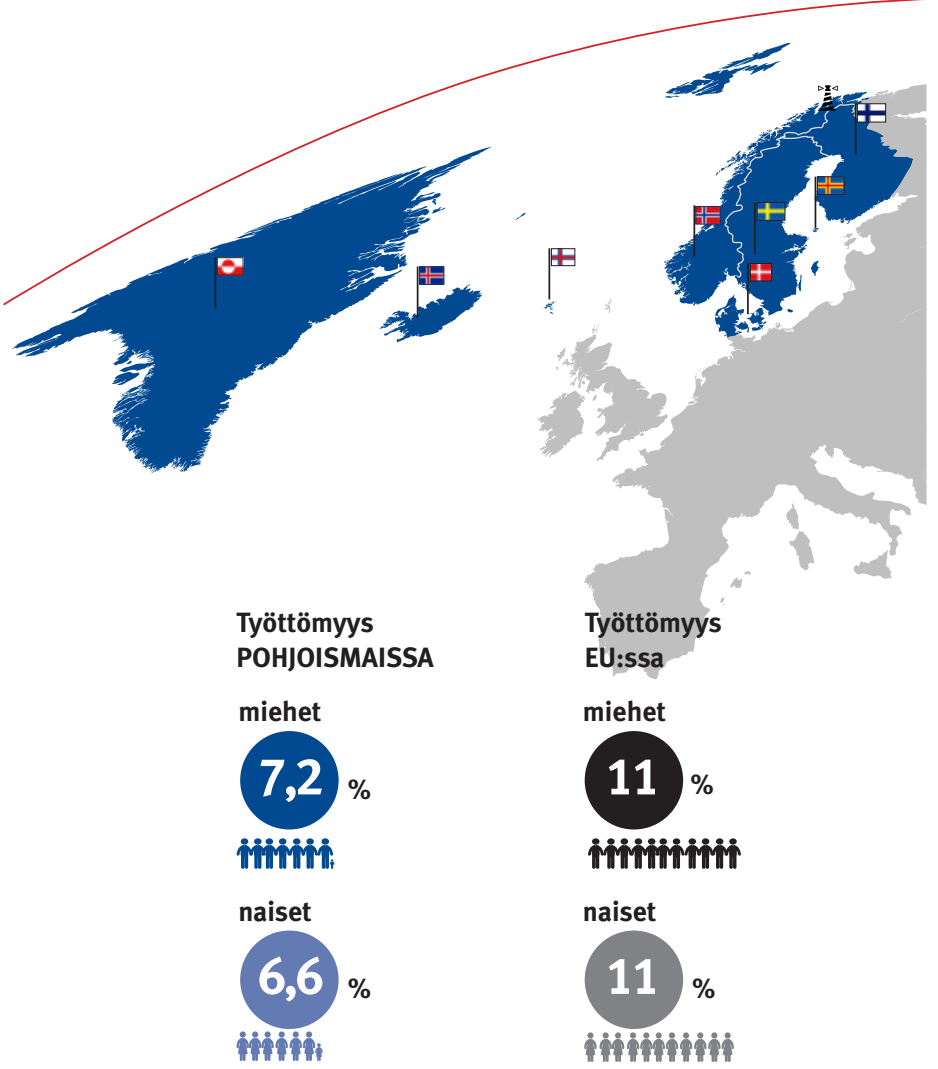


. statistic.

15 Pohjola tilasto. statistics 2015 Nordisk s Pohjola tilastoina 2015 No stics 2015 Nordisk statistik 21 ola tilastoina 2015 Nordic Stat ; Nordisk statistik 2015 Pohjol jina 2015 Nordic Statistics : k statistik 2015 Pohjola til rdic Statistics $2015 \mathrm{Nr}$

115 Pohjola tilastr

? $21 \mathrm{E}$. 
Tiesitkö, että...

vuoden 1995 jälkeen

Pohjoismaiden

taloudet ovat lähes

kaksinkertaistuneet

samaan aikaan, kun

hiilidioksidipäästöt ovat

supistuneet lähes 20

prosenttia?

(Lähde: Nordisk statistik)

Ilmasto ja energia 
... ja että Pohjoismaat

ovat 25 vuotta edellä

muuta maailmaa hiilen

vähentämisessä

sähköntuotannossa?

(Lähde: IEA) 


\section{Pohjoismaiden pääkaupunkien keskilämpötila}

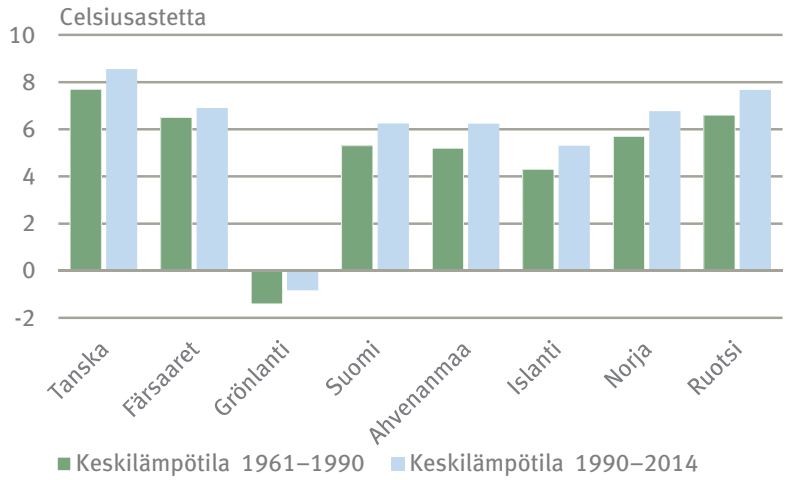

皿 Temp01. Färsaaret, Islanti, Norja ja Ruotsi: tiedot vuodelta 1990-2013. Islanti: tiedot vuodelta 1997-2014.

\section{Kasvihuonekaasupäästöt asukasta kohden}

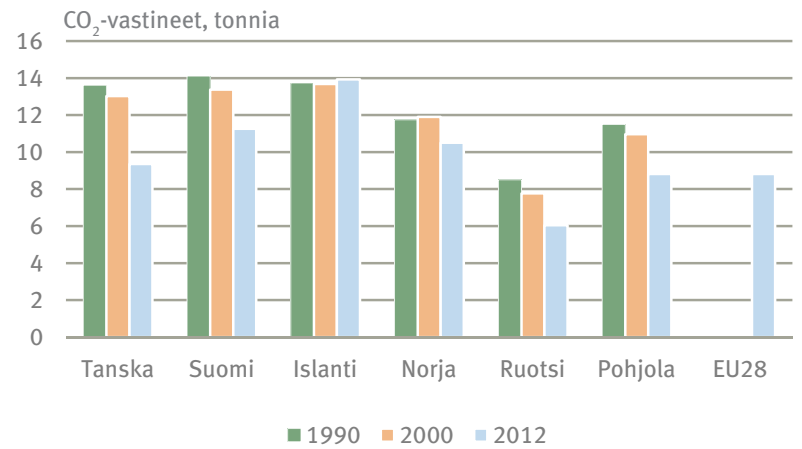

Emis11 ja Popu02 
Kotimainen energiantuotanto 2013

\section{Pohiola}

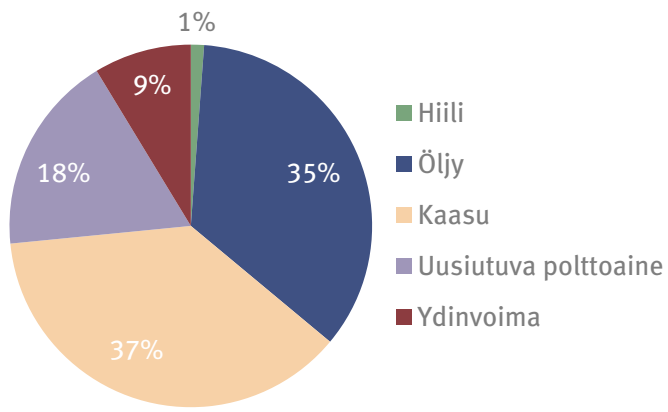

토은

Kotimainen energiantuotanto 2013

\section{EU27}

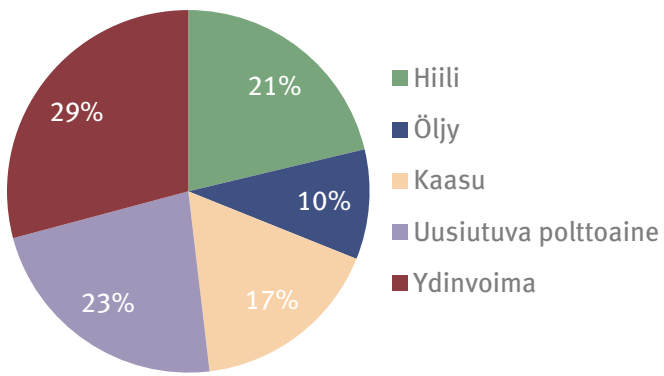

Ener06. EU27: tiedot vuodelta 2012. 


\section{Energialähteet 2013}

\section{Pohjola}

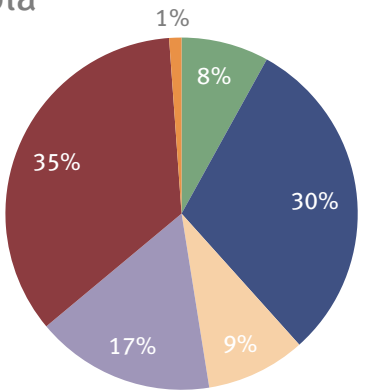

Ener05

\section{Energialähteet 2013}

\section{EU28}

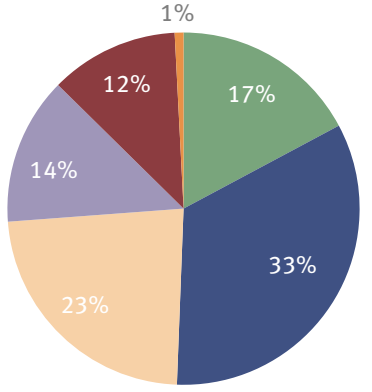

a Hiili

- Öljy

Kaasu

-Ydinvoima

- Uusiutuva pottoaine

muut

몰 05 
Energian loppukulutus 2013

\section{Pohjola}

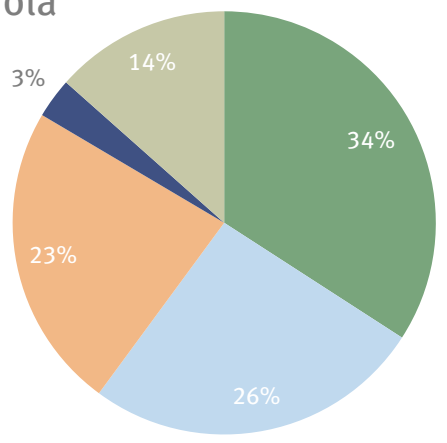

- Teollisuus

- Liikenne

- Kotitaloudet

- Maatalous ja kalatalous

- Palvelut ja muut toimialat

므 Ener10

Energian loppukulutus 2013

\section{EU28}

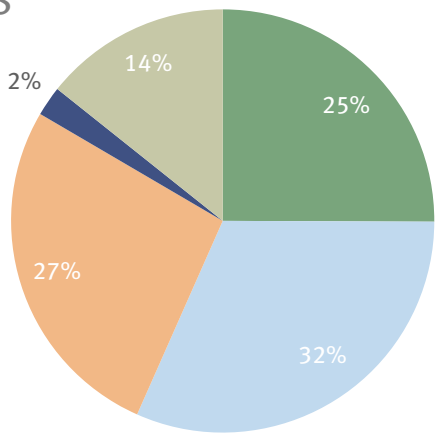

- Teollisuus

- Liikenne

- Kotitaloudet

- Maatalous ja kalatalous

n Palvelut ja muut toimialat 
Ympäristökuormituksen irtikytkentä talouskasvusta

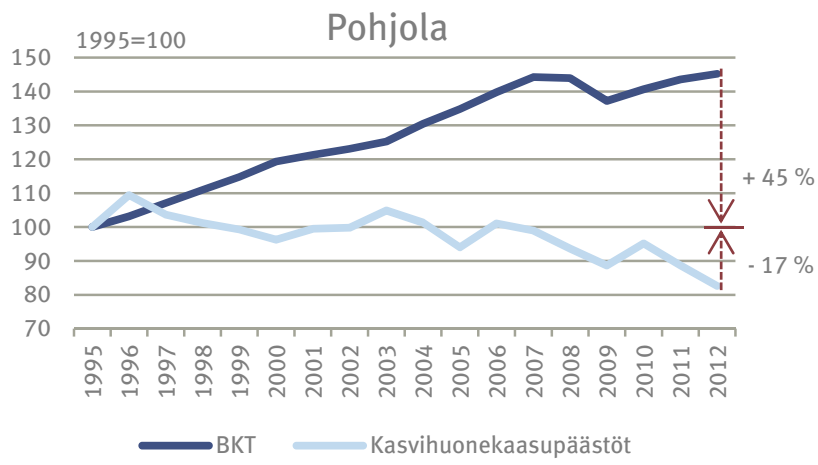

@ Indic401

\section{Ympäristökuormituksen irtikytkentä talouskasvusta}

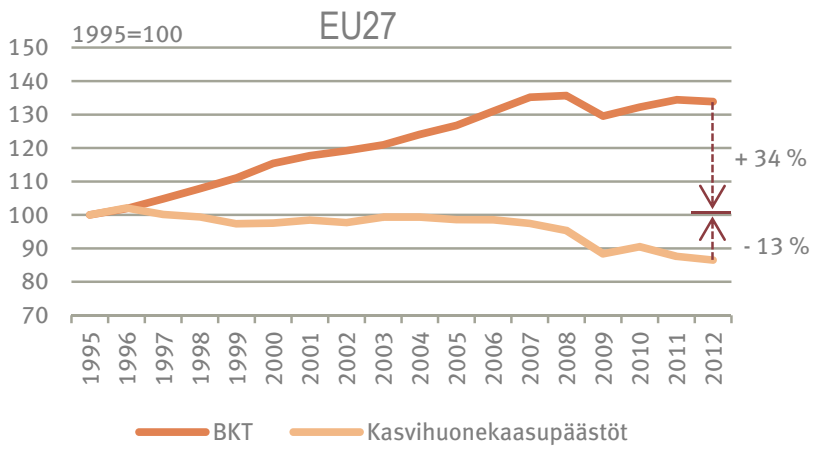

昌 Indic401 


\section{Ympäristöverot}

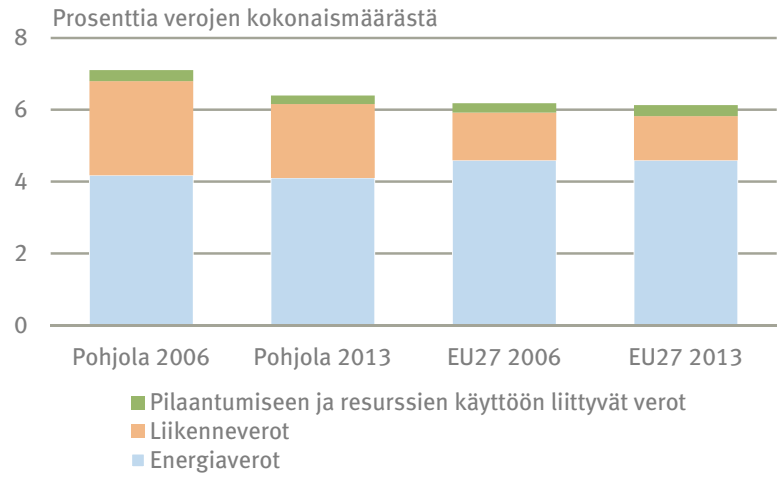

口Pubs15 


\section{Luonnonmukainen viljely 2013}

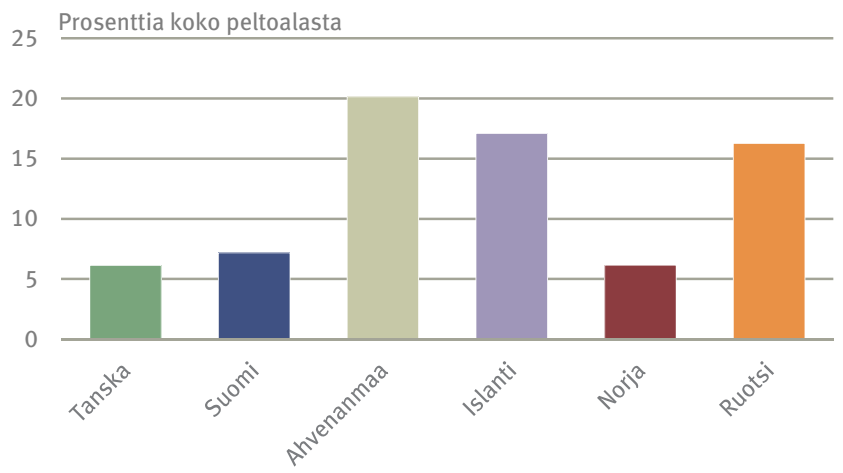

Oeno01. Suomi, Norja ja Ruotsi: tiedot vuodelta 2012. 
. statistic.

15 Pohjola tilasto.

statistics 2015 Nordisk s

Pohjola tilastoina 2015 No

stics 2015 Nordisk statistik 21

ola tilastoina 2015 Nordic Stat

; Nordisk statistik 2015 Pohjol

jina 2015 Nordic Statistics:

k statistik 2015 Pohjola til

rdic Statistics $2015 \mathrm{Nr}$

115 Pohjola tilastr

- 2n1 E A. 


\section{Tiesitkö, että...}

\section{3 prosenttia}

Pohjoismaiden

työvoimasta työskentelee julkisella sektorilla?

(Lähde: Nordisk statistik)

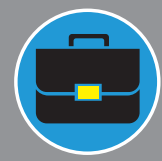

Työmarkkinat 


\section{Työllisyysaste 2014}

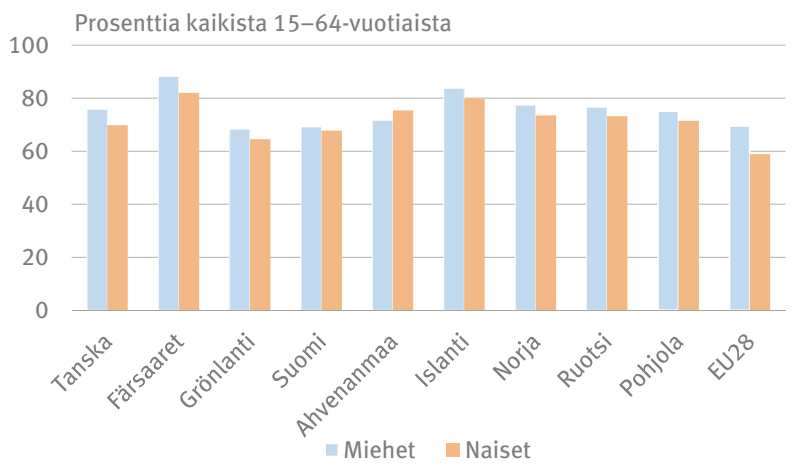

Työvoima sukupuolen mukaan 2014

\section{Pohjola}

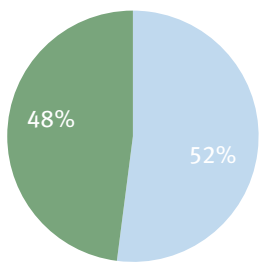

\section{EU28}

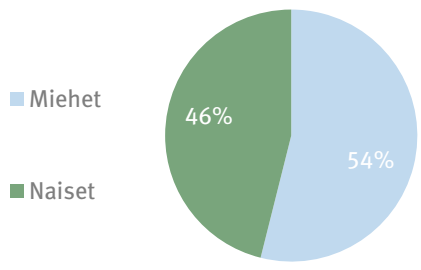

Work02. Ahvenanmaa: tiedot vuodelta 2011. Grönlanti, Suomi, Islanti ja Norja: tiedot vuodelta 2013. 


\section{Työttömyysaste}

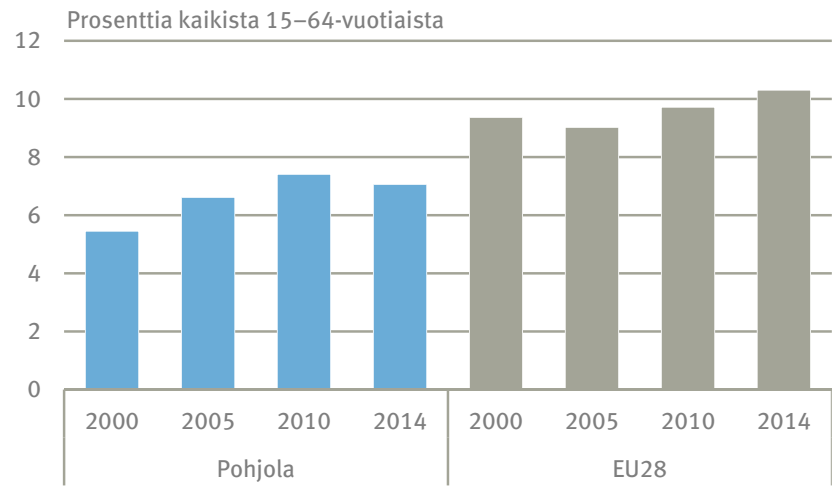

므 Work02

\section{Nuorten työttömyysaste}

Prosenttia kaikista 15-24-vuotiaista

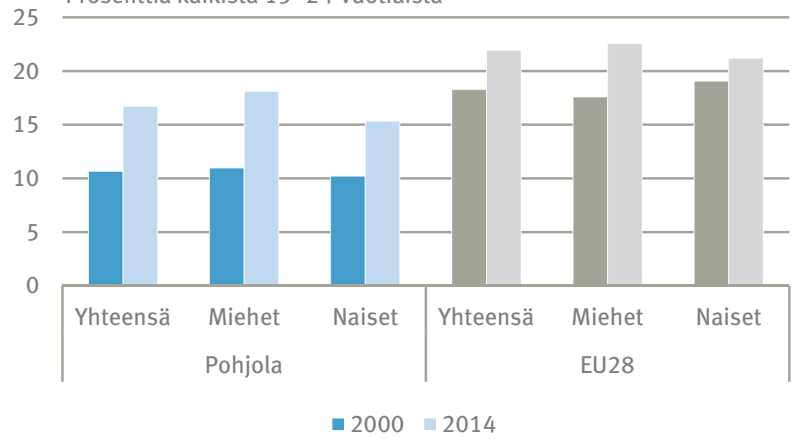

ㅁork02 


\section{Poissaolo työstä vähintään viikon sairauden vuoksi}

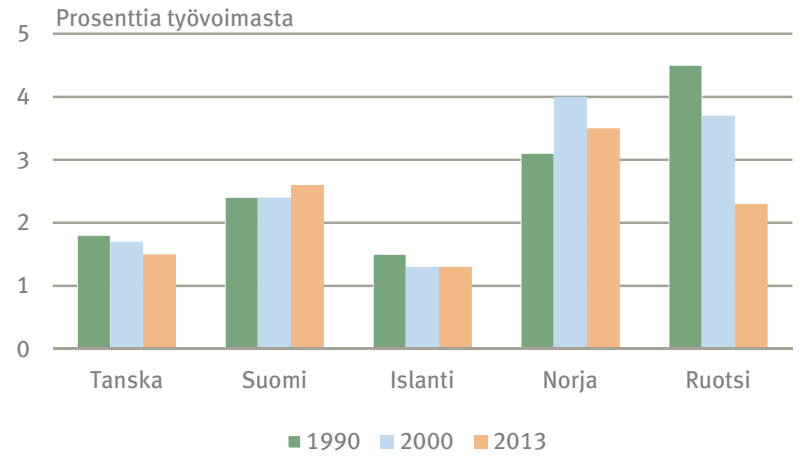

Soci02

Poissaolo työstä vähintään viikon sairauden vuoksi 2013

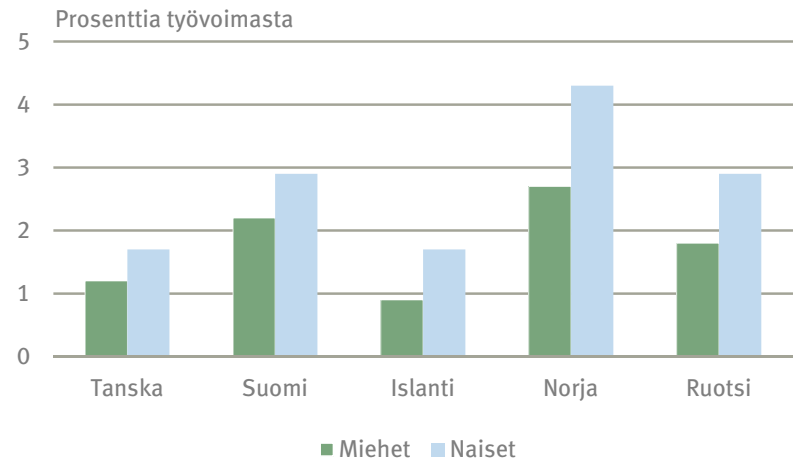

모인 2 


\section{Äitiys- ja isyysvapaa}

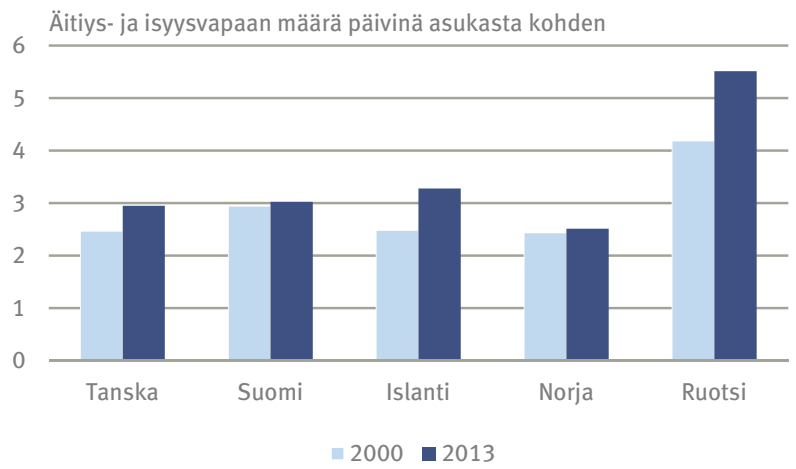

Soci04

Äitiys- ja isyysvapaa

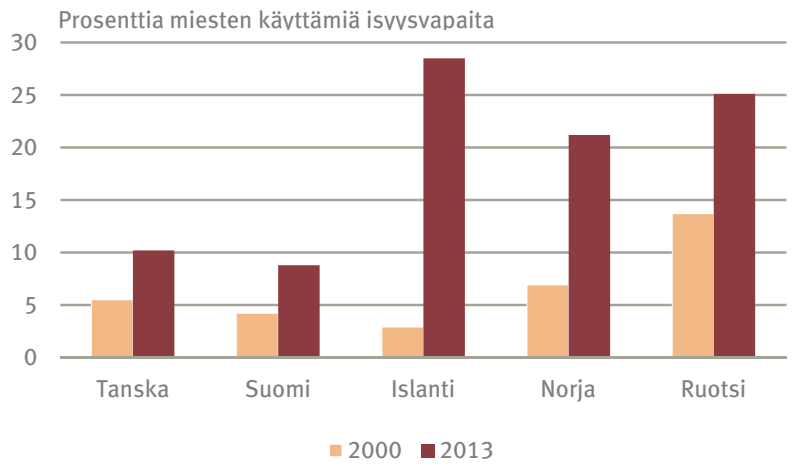

马Soci04. Ruotsi: tiedot vuodelta 2012. 


\section{Vuotuiset mediaanitulot 2013}

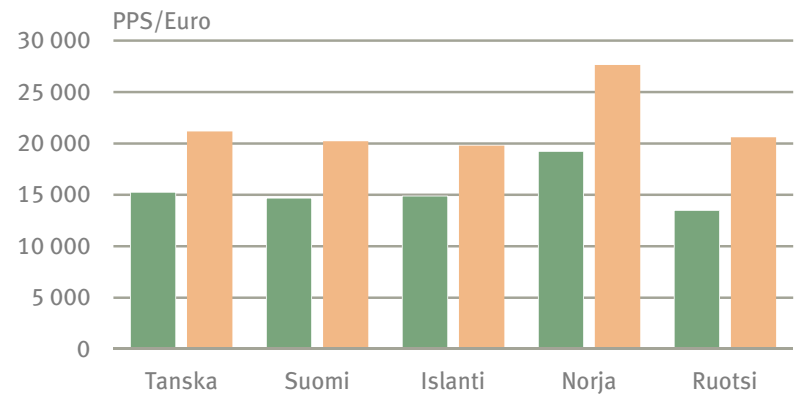

- Yksinhuoltaja Kaksi tai useampia aikuisia, joilla huollettavia lapsia

曰Inco02. Ruotsi: tiedot vuodelta 2012. 
Tiesitkö, että... kaksi kolmasosaa Pohjoismaiden naisista käy kokopäivätöissä?

(Lähde: Nordisk statistik) 
. statistic.

15 Pohjola tilasto.

statistics 2015 Nordisk s

Pohjola tilastoina 2015 No

stics 2015 Nordisk statistik 21

ola tilastoina 2015 Nordic Stat

; Nordisk statistik 2015 Pohjol

jina 2015 Nordic Statistics:

k statistik 2015 Pohjola til

rdic Statistics $2015 \mathrm{Nr}$

115 Pohjola tilastr

- 2n1 E A. 


\section{Tiesitkö, että...}

\section{Pohjoismaissa on}

lääkäreitä nykyään kolme kertaa enemmän asukasta kohden kuin 60-luvulla?

(Lähde: Nordisk statistik)

Koulutus ja tutkimus 
Koulutustaso (ikäryhmä 25-74 vuotta) 2014

Pohjola

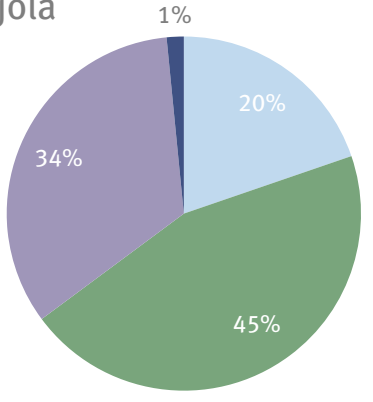

묨oc01
Peruskoulu (ISCED 1+2)

- Toisen asteen koulutus (ISCED 3+4)

- Korkeakoulututkinto (ISCED 5+6)

- Määrittelemätön tai tuntematon taso

Koulutustaso (ikäryhmä 25-74 vuotta) 2014

\section{EU27}

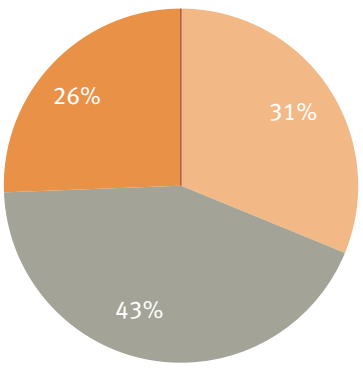

- Peruskoulu (ISCED 1+2)

- Toisen asteen koulutus (ISCED 3+4)

- Korkeakoulututkinto (ISCED 5+6)

- Määrittelemätön tai tuntematon taso 
Koululaisten osaaminen, PISA 2012

\begin{tabular}{|c|c|c|c|c|c|}
\hline \multicolumn{2}{|l|}{ Lukutaito } & \multicolumn{2}{|l|}{$\begin{array}{l}\text { Matematiikan } \\
\text { osaaminen }\end{array}$} & \multicolumn{2}{|l|}{$\begin{array}{l}\text { Luonnontieteen } \\
\text { osaaminen }\end{array}$} \\
\hline Japani & 538 & Etelä-Korea & 554 & Japani & 547 \\
\hline Etelä-Korea & 536 & Japani & 536 & Suomi & 545 \\
\hline Suomi & 524 & Sveitsi & 531 & Viro & 541 \\
\hline Kanada & 523 & Alankomaat & 523 & Etelä-Korea & 538 \\
\hline Irlanti & 523 & Viro & 521 & Puola & 526 \\
\hline Puola & 518 & Suomi & 519 & Kanada & 525 \\
\hline Viro & 516 & Kanada & 518 & Saksa & 524 \\
\hline Uusi-Seelanti & 512 & Puola & 518 & Alankomaat & 522 \\
\hline Australia & 512 & Belgia & 515 & Irlanti & 522 \\
\hline Alankomaat & 511 & Saksa & 514 & Australia & 521 \\
\hline Belgia & 509 & Itävalta & 506 & Uusi-Seelanti & 516 \\
\hline Sveitsi & 509 & Australia & 504 & Sveitsi & 515 \\
\hline Saksa & 508 & Slovenia & 501 & Yhd. kuningask. & 514 \\
\hline Ranska & 505 & Irlanti & 501 & Slovenia & 514 \\
\hline Norja & 504 & Uusi-Seelanti & 500 & Tšekki & 508 \\
\hline Yhd. kuningask. & 499 & Tanska & 500 & Itävalta & 506 \\
\hline Yhdysvallat & 498 & Tšekki & 499 & Belgia & 505 \\
\hline Tanska & 496 & Ranska & 495 & OECD & 501 \\
\hline OECD & 496 & OECD & 494 & Ranska & 499 \\
\hline Tšekki & 493 & Yhd. kuningask. & 494 & Tanska & 498 \\
\hline Italia & 490 & Islanti & 493 & Yhdysvallat & 497 \\
\hline Itävalta & 490 & Luxemburg & 490 & Espanja & 496 \\
\hline Unkari & 488 & Norja & 489 & Norja & 495 \\
\hline Portugali & 488 & Portugali & 487 & Unkari & 494 \\
\hline Espanja & 488 & Italia & 485 & Italia & 494 \\
\hline Luxemburg & 488 & Espanja & 484 & Luxemburg & 491 \\
\hline Israel & 486 & Slovakia & 482 & Portugali & 489 \\
\hline Islanti & 483 & Yhdysvallat & 481 & Ruotsi & 485 \\
\hline Ruotsi & 483 & Ruotsi & 478 & Islanti & 478 \\
\hline Slovenia & 481 & Unkari & 477 & Slovakia & 471 \\
\hline Kreikka & 477 & Israel & 466 & Israel & 470 \\
\hline Turkki & 475 & Kreikka & 453 & Kreikka & 467 \\
\hline Slovakia & 463 & Turkki & 448 & Turkki & 463 \\
\hline Chile & 441 & Chile & 423 & Chile & 445 \\
\hline Meksiko & 424 & Meksiko & 413 & Meksiko & 415 \\
\hline
\end{tabular}

ㄱisa01 


\section{0-39-vuotiaat yliopisto- ja korkeakouluopiskelijat}

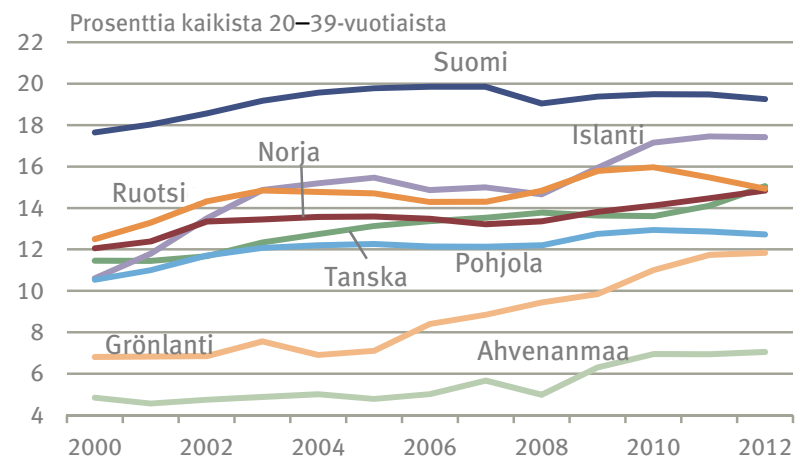

Educ02 ja Popu02

\section{0-39-vuotiaat yliopisto- ja korkeakouluopiskelijat}

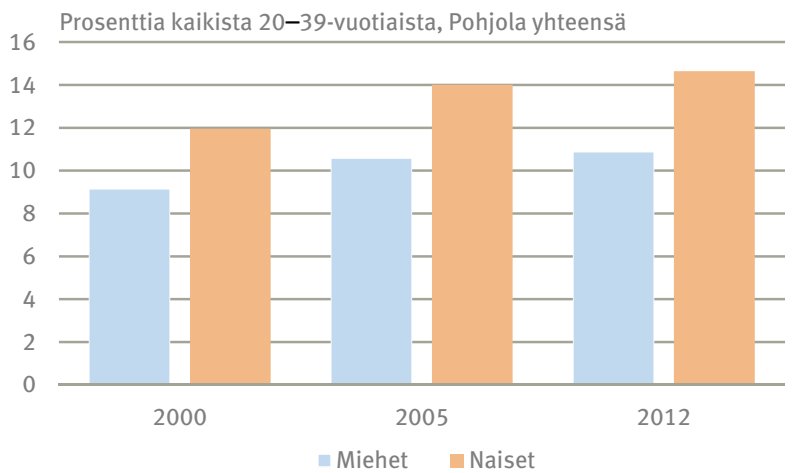

Educ02 ja Popu02 


\section{Taloudellinen tuki opiskelijoille 2013}

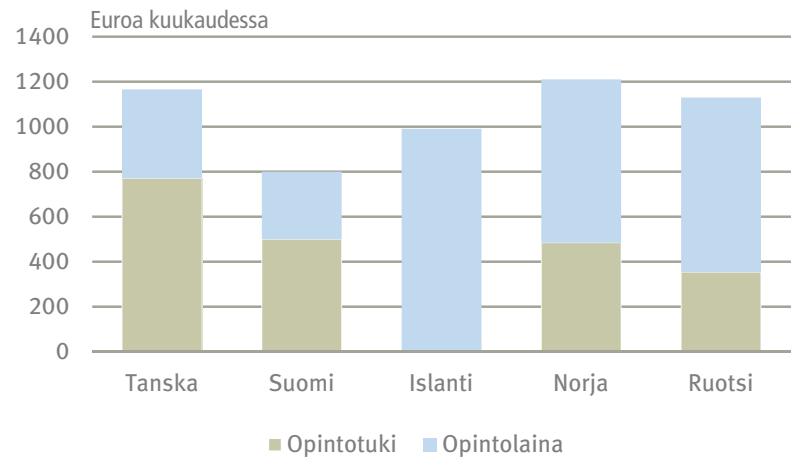

Educ07

\section{Filosofian tohtorit 2012}

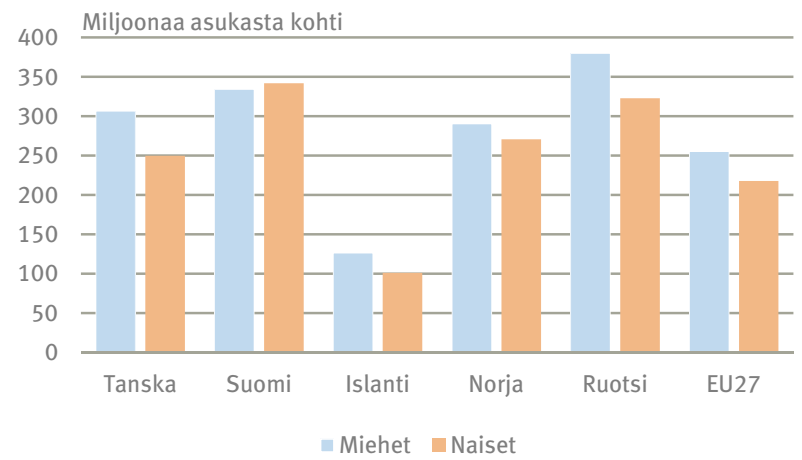

@ Phdg01 
Tutkimus- ja kehittämistoiminnan henkilöstö

3,0 Prosenttia työvoimasta

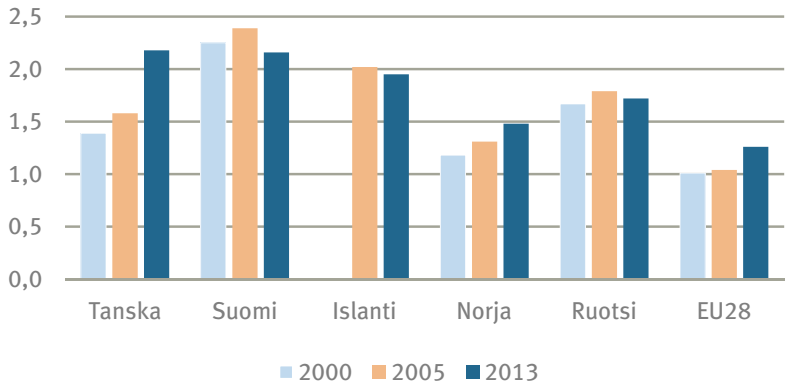

Bede04

Valtion tutkimus- ja kehittämistoiminnan menot

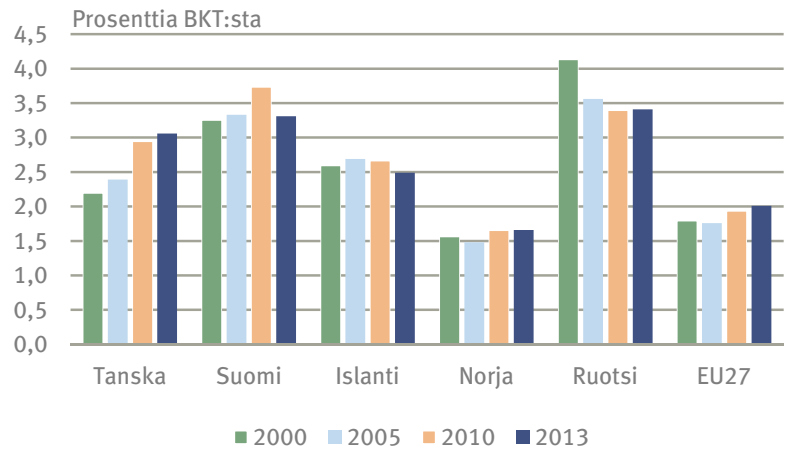

Bede01 
Uudet yritykset

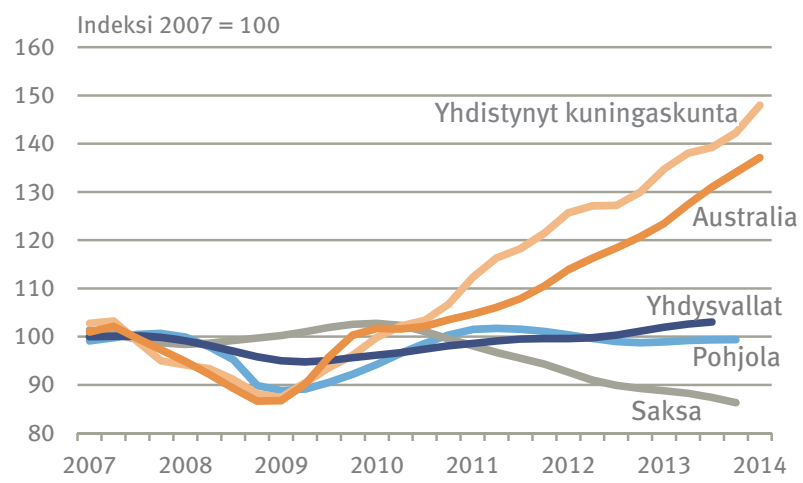

므tp02

Tiesitkö, että...

naisten osuus yliopisto-

opiskelijoista on

kaksinkertaistunut

60-lukuun verrattuna?

Nykyään kuusi

kymmenestä yliopisto-

opiskelijasta on naisia.

(Lähde: Nordisk statistik) 
. statistic.

15 Pohjola tilasto.

statistics 2015 Nordisk s

Pohjola tilastoina 2015 No

stics 2015 Nordisk statistik 21

ola tilastoina 2015 Nordic Stat

; Nordisk statistik 2015 Pohjol

jina 2015 Nordic Statistics:

k statistik 2015 Pohjola til

rdic Statistics $2015 \mathrm{Nr}$

115 Pohjola tilastr

- 2n1 E A. 
Tiesitkö, että...

vuodesta 2000 alkaen

muut mediat kuin kirjat ovat Pohjoismaissa kasvattaneet osuuttaan 30-80 prosenttia kun samanaikaisesti kirjalainojen määrä on laskenut 10-20 prosenttia?

(Lähde: Nordisk statistik)

Innovaatio ja luovuus 


\section{Patentit 2014}

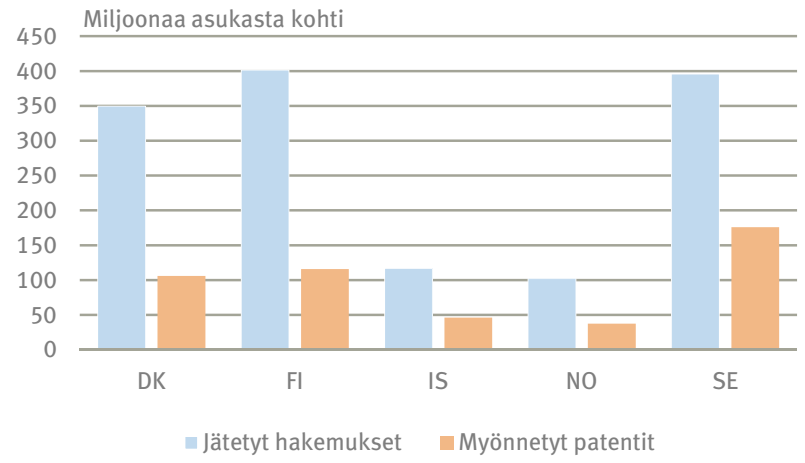

Pate01

\section{Työllisyys kulttuurialalla}

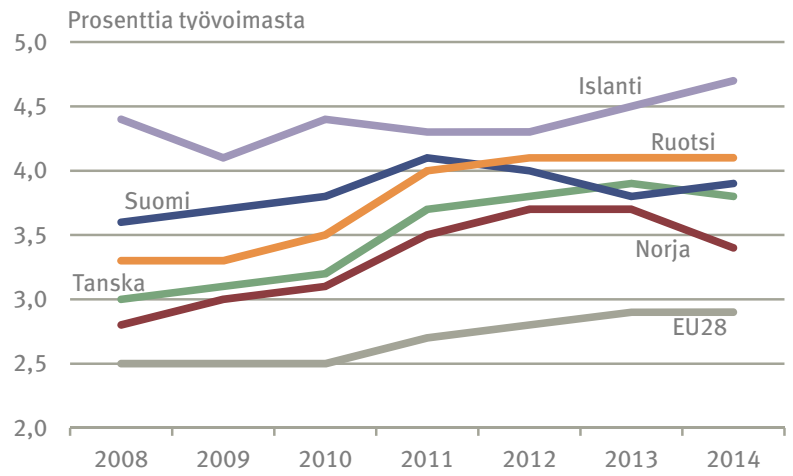


Kulttuurin ja vapaa-ajan toiminnan julkinen rahoitus 2013

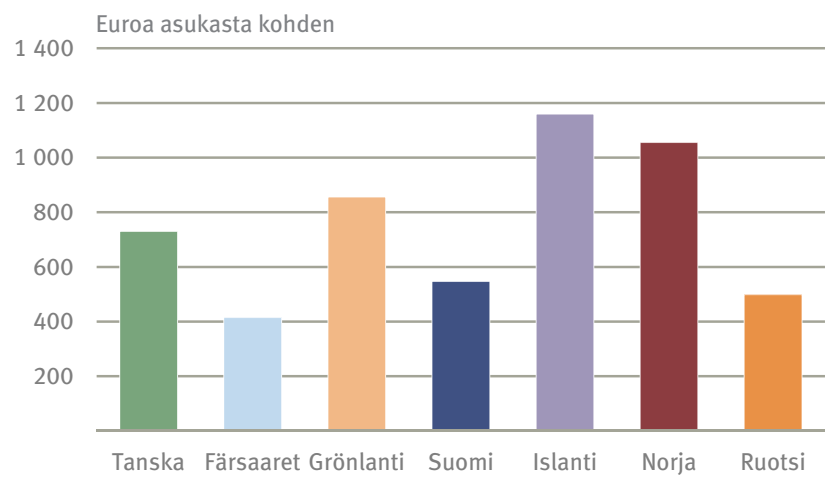

ㅁ Cult20. Färsaaret: tiedot vuodelta 2009. Grönlanti: tiedot vuodelta 2012.

Kulttuurin ja vapaa-ajan toiminnan julkinen rahoitus 2013

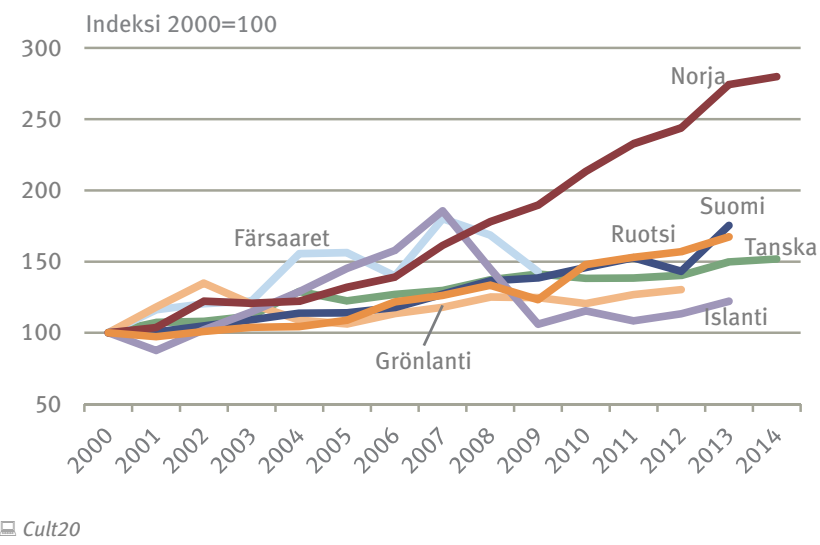




\section{Elokuvaensi-illat 2013}

Prosenttia pohjoismaisista elokuvaensi-illoista

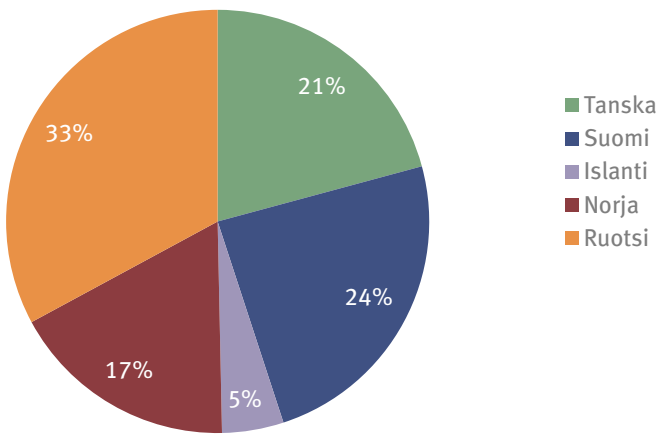

ㅁolt05

\section{Elokuvaensi-illat 2013}

300 Lukumäärä

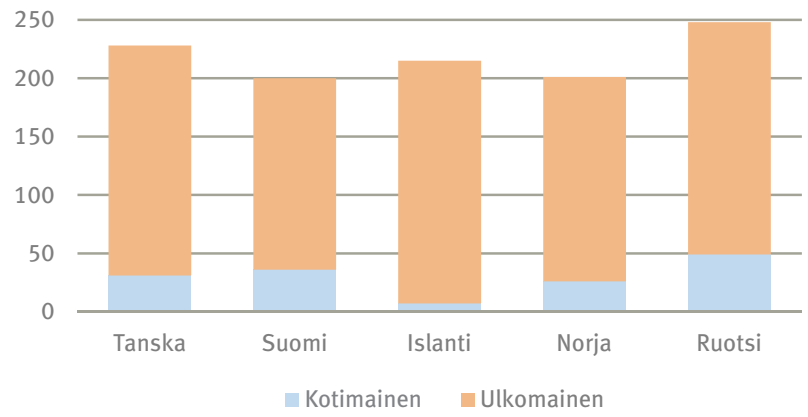

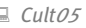




\section{Teatterikäynnit 2014}

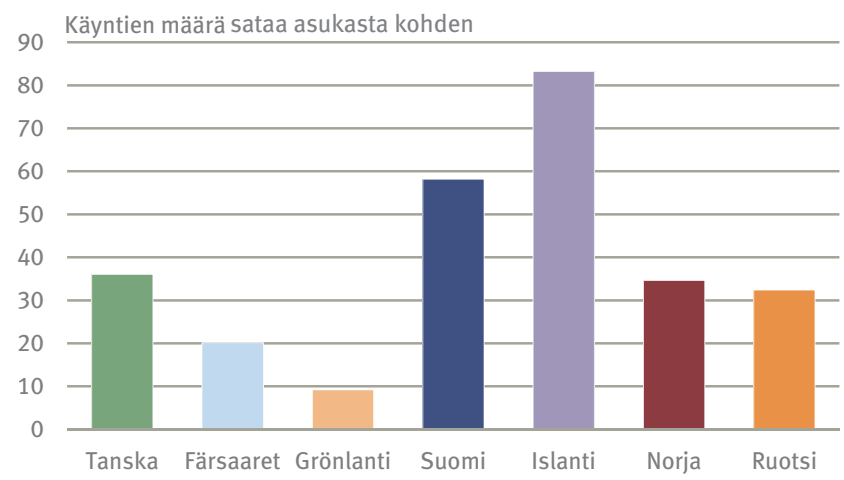

므 Cult15. Islanti: tedot vuodelta 2012. Ruotsi: tiedot vuodelta 2010.

Tiesitkö, että...

Pohjolassa on yhteensä 406 teatteria, joissa järjestetään vuosittain yli 60000 esitystä?

(Lähde: Nordisk statistik) 
. statistic.

15 Pohjola tilasto.

statistics 2015 Nordisk s

Pohjola tilastoina 2015 No

stics 2015 Nordisk statistik 21

ola tilastoina 2015 Nordic Stat

; Nordisk statistik 2015 Pohjol

jina 2015 Nordic Statistics:

k statistik 2015 Pohjola til

rdic Statistics $2015 \mathrm{Nr}$

115 Pohjola tilastr

- 2n1 E A. 


\section{Tiesitkö, että...}

Pohjoismailla on parhaat mahdollisuudet saavuttaa YK:n kestävän kehityksen tavoitteet?

(Lähde: Sustainable Governance Indicators 2015)

... ja että elinajanodote Pohjoismaiden naisilla on nyt 84 vuotta? 60-luvun alussa naisten elinajanodote oli "vain" 74 vuotta.

(Lähde: Nordisk statistik)

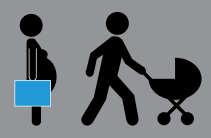

Sosiaalipalvelut ja yhdenvertaisuus 


\section{Gini-kerroin 2013}

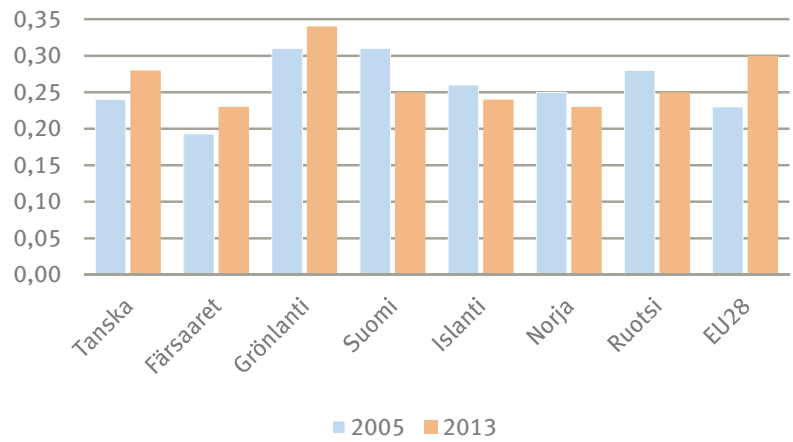

@ Gini01. Färsaaret: vuoden 2005 tiedot ovat vuodelta 2009.

EU28: tiedot vuodelta 2005 kattavat vain EU 27:n.

\section{Sosiaalimenojen rahoituksen lähteet 2012}

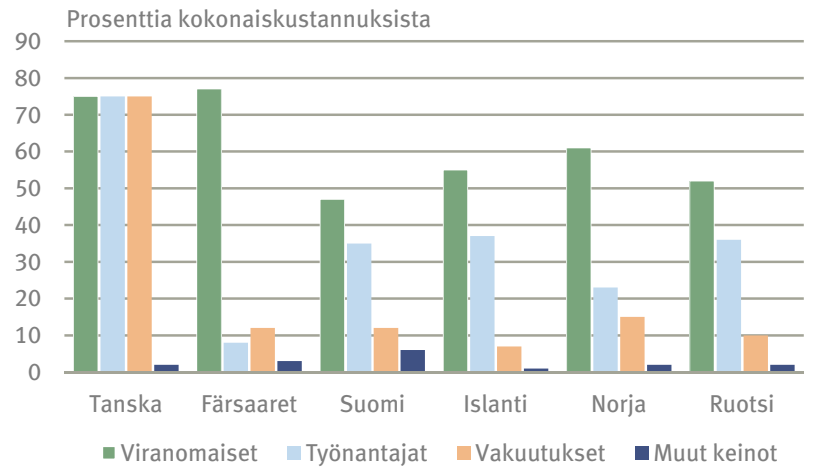




\section{Toimeentulotuen saajat 2013}

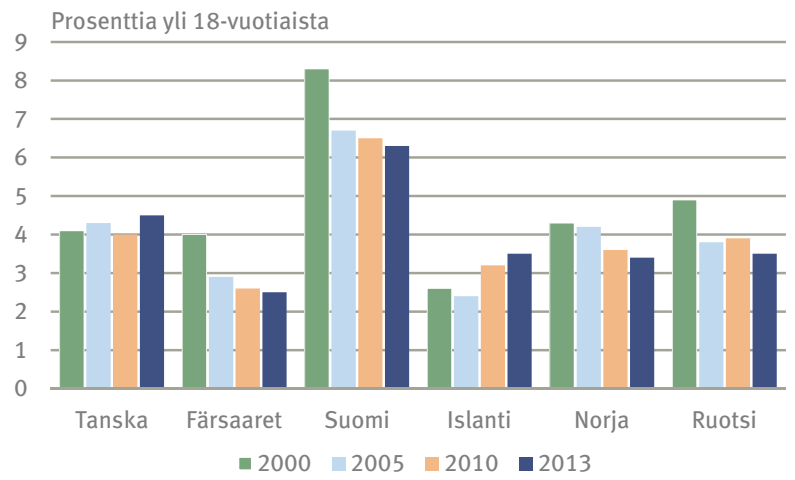

马 Soci12. Färsaaret: vuoden 2013 tiedot ovat vuodelta 2011.

Suomi ja Norja: vuoden 2013 tiedot ovat vuodelta 2012.

\section{Köyhyysriski 2013}

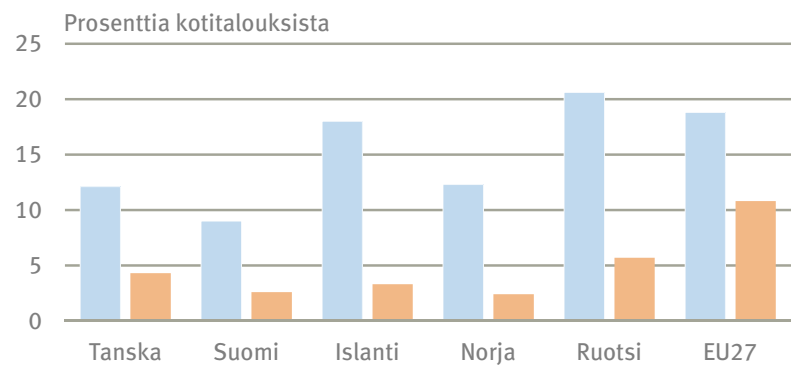

= Yksinhuoltaja $\square$ Kaksi tai useampia aikuisia, joilla huollettavia lapsia 
Sukupuolten palkkaero (miesten eduksi)

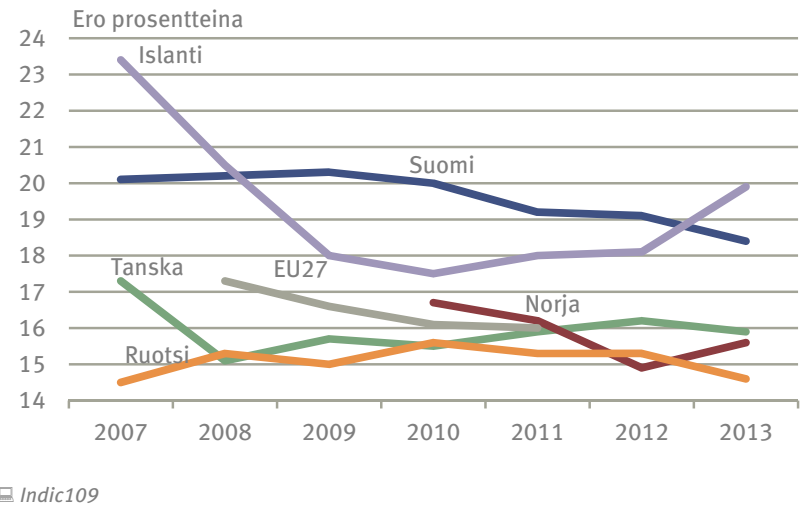

Kansallisiin parlamentteihin valitut, viimeisimmät vaalit

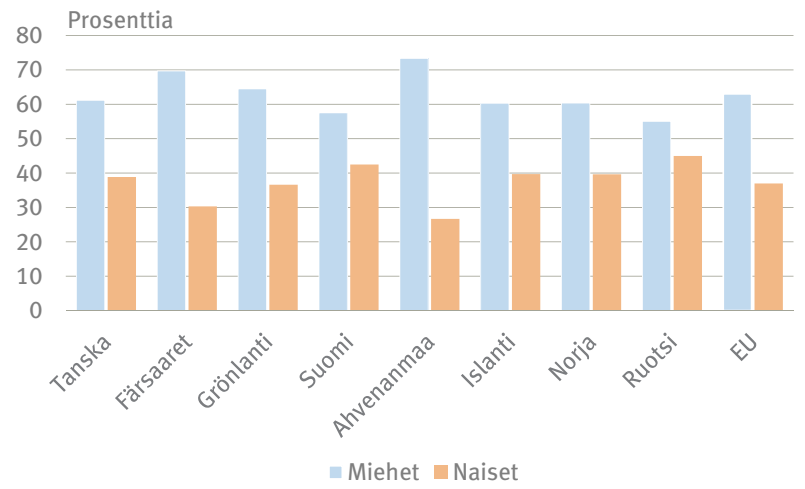

Ele03 
Hyväksytyt äänet kaksissa viimeisimmissä kansallisissa vaaleissa

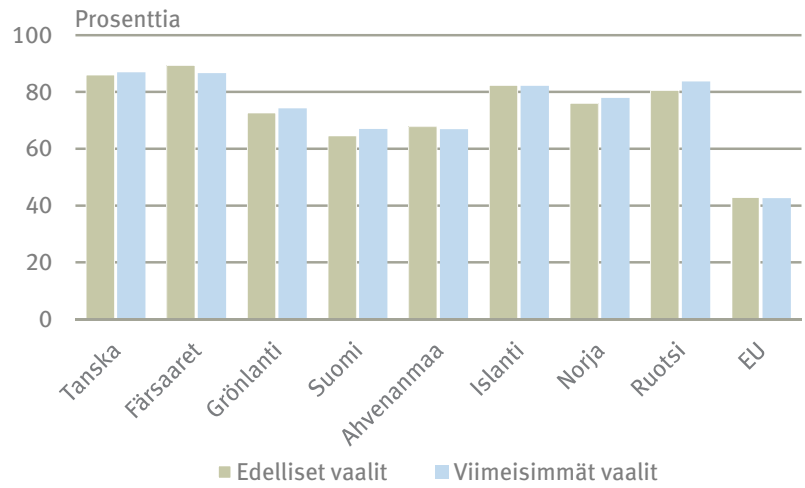

Ele01

Maahanmuutto Pohjoismaihin 2014

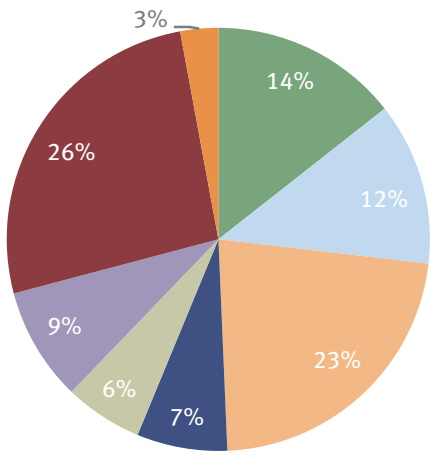

- Pohjoismaiden sisäinen

Puola ja Baltia

m Muu ETA

- Muu Eurooppa

罣Amerikka

afrikka

- Aasia

muut

Migr01 
. statistic.

15 Pohjola tilasto.

statistics 2015 Nordisk s

Pohjola tilastoina 2015 No

stics 2015 Nordisk statistik 21

ola tilastoina 2015 Nordic Stat

; Nordisk statistik 2015 Pohjol

jina 2015 Nordic Statistics:

k statistik 2015 Pohjola til

rdic Statistics $2015 \mathrm{Nr}$

115 Pohjola tilastr

- 2n1 E A. 



\section{Siirtolaisuus Pohjoismaista 2014}

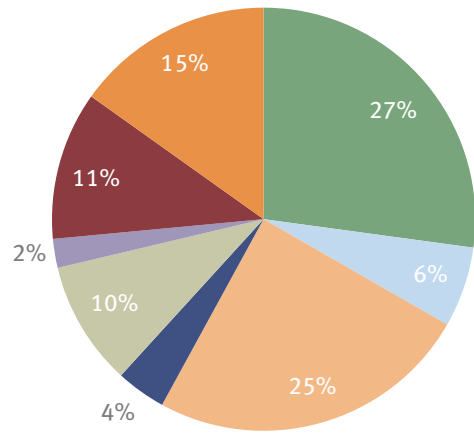

- Pohjoismaiden sisäinen

- Puola ja Baltia

- Muu ETA

- Muu Eurooppa

- Amerikka

- Afrikka

- Aasia

muut

모․ Migr02. Suomi: tiedot vuodelta 2013.

\section{Turvapaikkahakemukset ja myönteiset päätökset Pohjoismaissa}

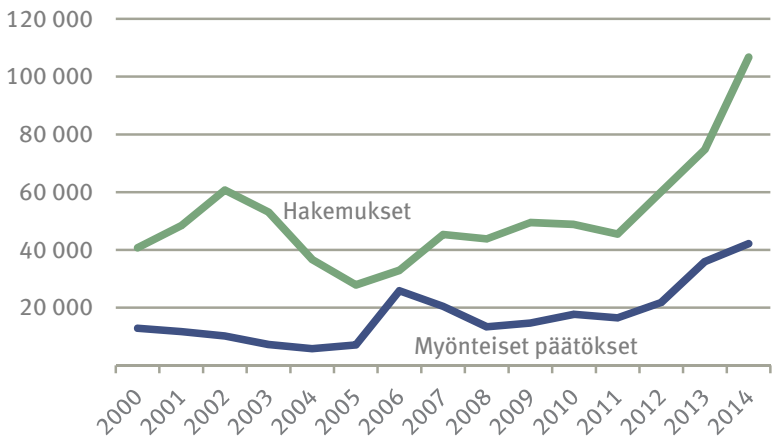




\section{Turvapaikkahakemukset Pohjoismaissa 2014}

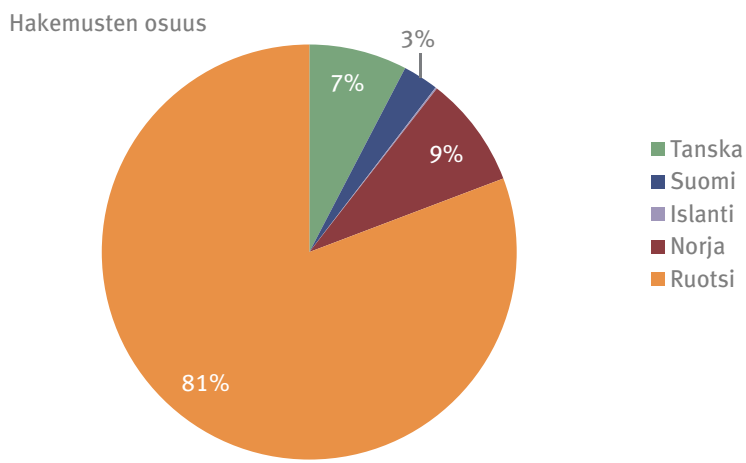

Migr04. Suomi: tiedot vuodelta 2013.

Myönnetyt turvapaikat Pohjoismaissa 2014

Myönteisten päätösten osuus

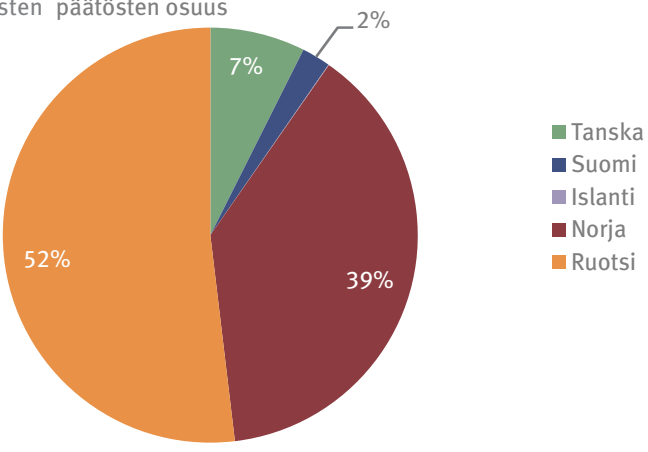

曰 Migr04. Suomi: tiedot vuodelta 2013. 
Ilman huoltajaa turvapaikkaa hakevat lapset

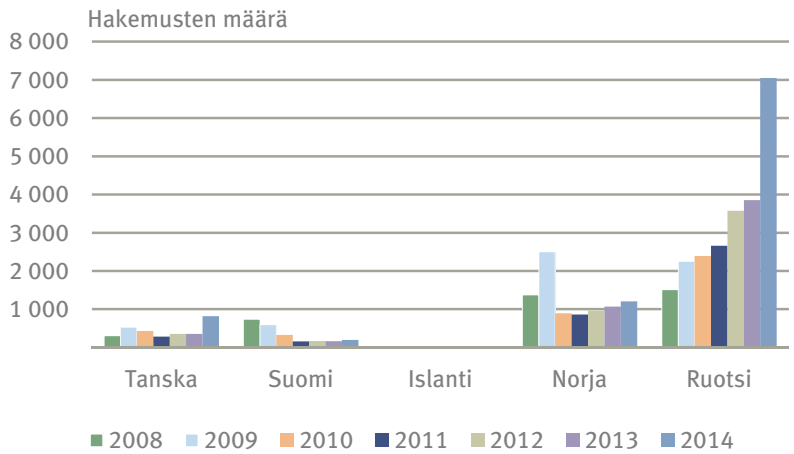

ㅂigr05 
Tiesitkö, että...

viime vuosien

aikana vuosittaisten

turvapaikkahakemusten

määrä Pohjoismaissa

on vaihdellut $45000 \mathrm{ja}$

75000 hakemuksen

välillä?

(Lähde: Nordisk statistik) 
. statistic.

15 Pohjola tilasto.

statistics 2015 Nordisk s

Pohjola tilastoina 2015 No

stics 2015 Nordisk statistik 21

ola tilastoina 2015 Nordic Stat

; Nordisk statistik 2015 Pohjol

jina 2015 Nordic Statistics:

k statistik 2015 Pohjola til

rdic Statistics $2015 \mathrm{Nr}$

115 Pohjola tilastr

- 2n1 E A. 
Tiesitkö, että... Pohjoismaiden yhteenlaskettu BKT on 1,5 biljoonaa euroa ja näin ollen maat muodostavat maailman kahdenneksitoista suurimman talouden?

(Lähde: Maailmanpankki)

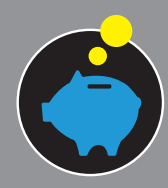

Talous 
Talouden avainluvut $2014^{1}$

Tanska Suomi Islanti Norja Ruotsi EA19

Prosenttia BKT:sta

Vaihtotaseen ylijäämä

$\begin{array}{rrrrr}6,3 & -1,9 & 3,6 & 8,5 & 6,3 \\ 40,0 & 46,0 & -422,0 & 134,0 & . .\end{array}$

Ulkomaiset saamiset

(netto), 31.12.

Julkisen talouden

$1,2 \quad-3,2 \quad-0,2 \quad 9,1 \quad-1,9$

ylijäämä

Julkisen talouden

$\begin{array}{llllll}45,2 & 59,3 & 99,0 & 26,4 & 43,9 & 91,9\end{array}$

velka, 31.12.

Prosenttia

\begin{tabular}{lrrrrrr}
\hline Työttömyys & 6,6 & 8,7 & 5,0 & 3,5 & 7,9 & 11,6 \\
Korko & 1,3 & 1,4 & 6,4 & 2,5 & 1,7 &..
\end{tabular}

Muutos 2013-2014,

prosenttia

\begin{tabular}{|c|c|c|c|c|c|c|}
\hline $\begin{array}{l}\text { Kuluttajahintojen } \\
\text { nousu }\end{array}$ & 0,3 & 1,2 & 1,0 & 1,9 & 0,2 & 0,4 \\
\hline Taloudellinen kasvu & 0,4 & $-1,4$ & 3,3 & 0,6 & 1,6 & $-0,4$ \\
\hline Osakekurssi-indeksi & 30,0 & 16,6 & 11,9 & 15,7 & 13,5 & \\
\hline $\begin{array}{l}\text { Nimellinen efektiivinen } \\
\text { valuuttakurssi-indeksi }\end{array}$ & $-8,4$ & $-8,5$ & $-8,8$ & $-8,3$ & $-8,3$ & \\
\hline
\end{tabular}

@ Key01. ${ }^{1} 2014$ tai uusin saatavilla oleva luku. Työttömyysluvut on yhdenmukaistettu. EA19: 19 EU:n jäsenvaltiota, jotka olivat ottaneet 1. tammikuuta 2015 mennessä euron valuutakseen.

\section{Tiesitkö, että...}

yli 70 prosenttia

Pohjoismaiden

työvoimasta työskentelee

palvelualalla?

(Lähde: Nordisk statistik) 


\section{BKT henkeä kohti}

$$
40000 \text { PPP/euro }
$$

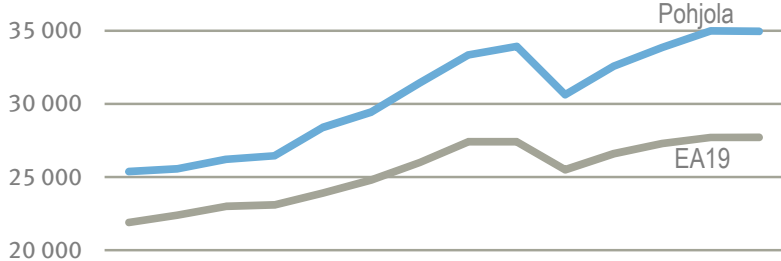

15000

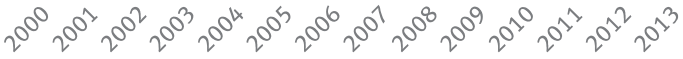

묘 Inic102

\section{BKT henkeä kohti}

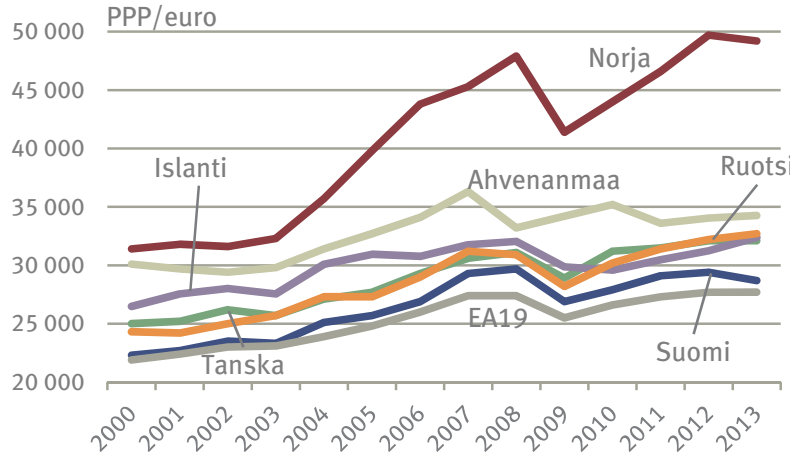

口 Indic102. EA19: 19 EU:n jäsenvaltiota, jotka olivat ottaneet 1. tammikuuta 2015 mennessä euron valuutakseen. 


\section{BKT - reaalinen vuosikasvu}

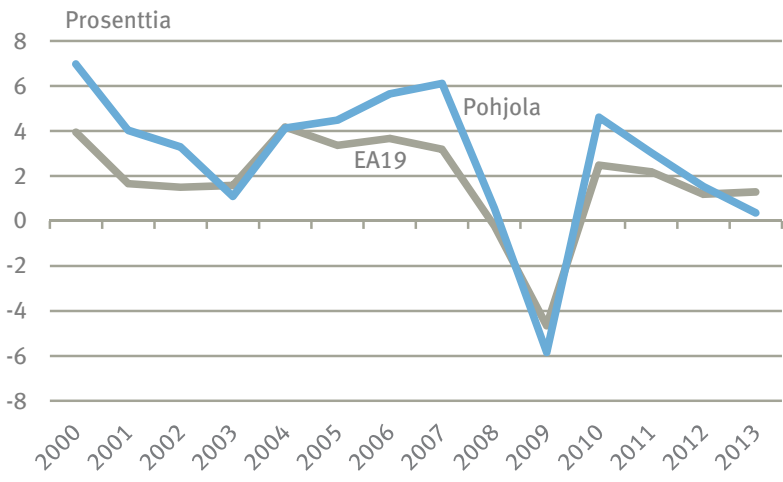

皿 Naac04. EA19: 19EU:n jäsenvaltiota, jotka olivat ottaneet 1. tammikuuta 2015 mennessä euron valuutakseen.

\section{BKT - reaalinen vuosikasvu}

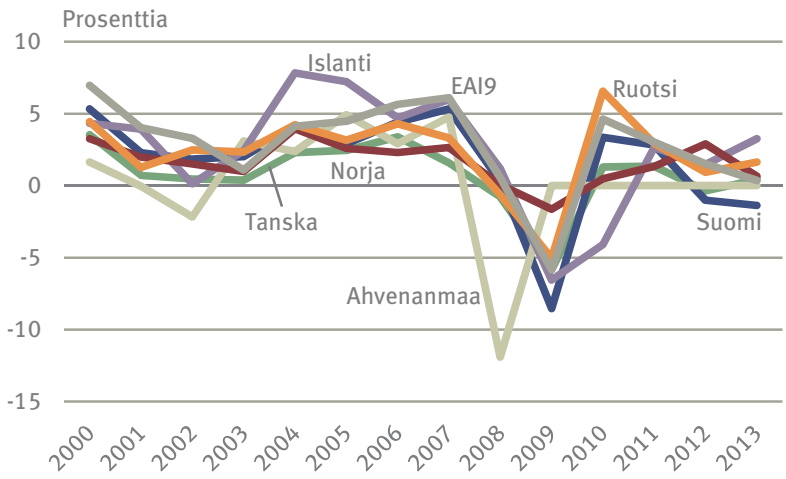

Naac04. EA19: 19 EU:n jäsenvaltiota, jotka olivat ottaneet 1. tammikuuta 2015 mennessä euron valuutakseen. 
Kauppatase - vienti miinus tuonti

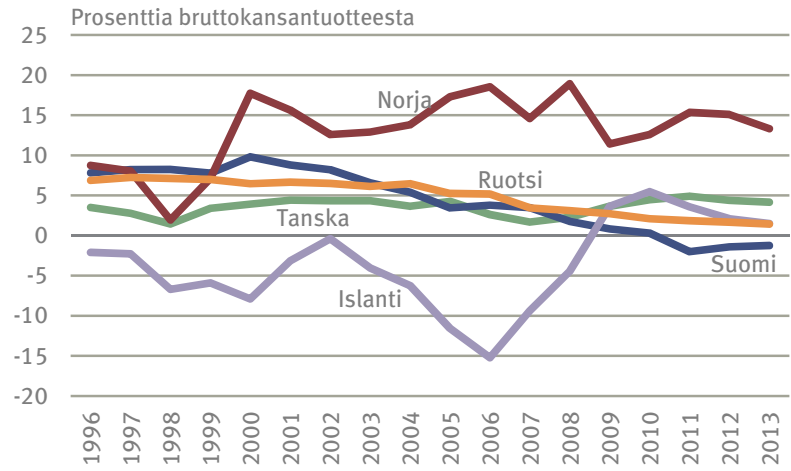

Fotr49

\section{Pohjoismaiden välinen kauppa}

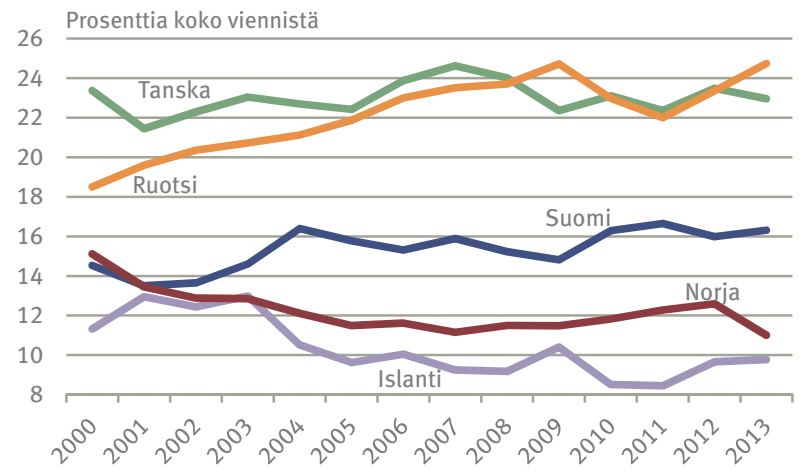




\section{Pohjoismaiden välinen kauppa}

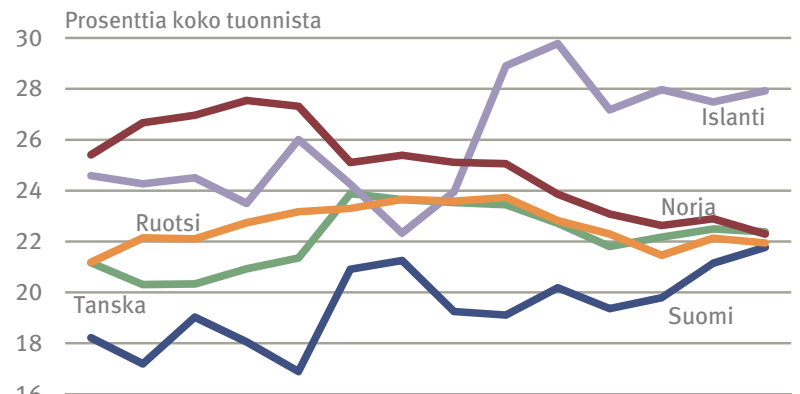

16

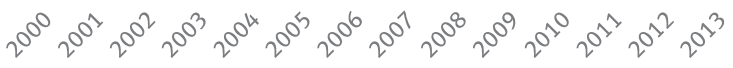

Eotr43

Tiesitkö, että...

viidesosa ulkomaankaupasta

Pohjoismaissa on kauppaa muiden Pohjoismaiden kanssa?

(Lähde: Nordisk statistik) 
J15 Pohjola tilasto. statistics 2015 Nordisk s Pohjola tilastoina 2015 No stics 2015 Nordisk statistik 21 ola tilastoina 2015 Nordic Stat i Nordisk statistik 2015 Pohjol jina 2015 Nordic Statistics: k statistik 2015 Pohjola til rdic Statistics $2015 \mathrm{Nr}$ 115 Pohjola tilastr

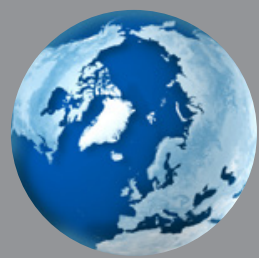

- int c : 


\section{norden}

\section{Pohjoismaiden ministerineuvosto}

\section{Pohjola tilastoina 2015}

Tässä julkaisussa on vain pieni valikoima pohjoismaisia tilastoja.

Vieraile osoitteessa www.norden.org/tietoa ja tutustu tarkemmin Pohjolan ja Pohjoismaiden lukuihin sekä tilastoihin.

Lisää tilastoja osoitteessa www.norden.org/tietoa

ANP 2015:782

ISBN 978-92-893-4368-8 (PRINT) ISBN 978-92-893-4369-5 (PDF) ISSN 0908-4339 